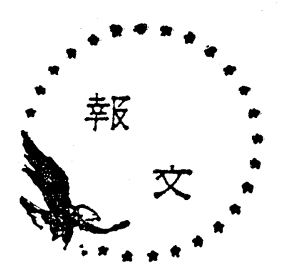

\section{弱粘結炭を原料とする溶鉱炉用成型 コークス製造に関する研究（II）}

一昭和 37 年 10 月 19 日受 理一

\section{I. 緒 言}

第 1 報で弱粘結炭, 非粘結炭などの炭化度の若い石 炭を加圧成型して乾留すれば, 成型しない場合におけ るときよりも，コークス化現象がコークス製造の立場 から好ましい状態に進展し, その結果として, 生成コ 一クスの品質が向上することを実験室的に一応明らか にした。第 2 報ではさらにそのコークス化機構の究明 に諸般の研究を進めることにした。

\section{II . 成型炭の成型圧力と石炭粒子間隔}

石炭を加圧成型すると, 成型圧力の増加とともに, 成型炭内の石炭粒子間隔は狭められ，コークス化過程 において粘結作用が旨くおこなわれることは当然予想 される。それで成型圧力によつて石炭粒子間隔がどう 変化するかは非常に重要な意義を有することであり， この点を成型炭の検鏡試験により検討した。

\section{1. 実験方法}

\section{(1) 試 料}

これまでのべてきた石炭のうち, 弱粘結炭の田川炭 1 種, 非粘結炭の高松炭 1 種計 2 種を代表試料として 選んだ。両石炭は乾懆後 $1.5 \mathrm{~mm}$ 以下に砕き，それぞ れピッチ $10 \%$ （ピッチの粉砕粒度 $1.5 \mathrm{~mm}$ 以下）を配 合し，成型しないときは石炭とピッチの混合物をよく 混合したものをそのままで用い，成型炭は前報でのべ た成型炭製造方式で製造した。このときの成型炭の大 きさ淔径 $70 \mathrm{~mm}$, 高さ $30 \mathrm{~mm}$ の円筒形である。し かして成型炭の成型圧力は $100 \mathrm{~kg} / \mathrm{cm}^{2}, 200 \mathrm{~kg} / \mathrm{cm}^{2}$, $300 \mathrm{~kg} / \mathrm{cm}^{2} 3$ のよおりした。

（2）検鏡試験による粒子間隔の測定法

製造した成型炭の中央部より Fig. 17 に示すごと く, 長さ $40 \mathrm{~mm}$, 横 $40 \mathrm{~mm}$, 高さ $25 \mathrm{~mm}$ の寸法を有 する長方体を切出し, 前報のコークスの緻密度を測定 したときと同じ研磨要領で, 成型炭上面 (B) をよく 研磨する。つぎにこの面に存在する石炭粒子間隔を E. Daub 112１13) 氏の提案している方法によつて測定 した。
(1) Briquette

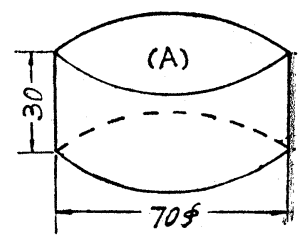

(2) Specimen for microscopic analysis

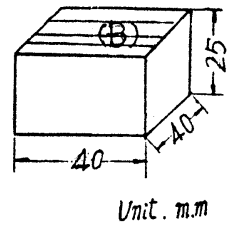

Fig. 17 Dimension of specimen for microscopic analysis

すなわちまず研磨した成型炭表面に存在する石炭粓 子間隔が予めどの程度の大きさの範囲にあるかを顕微 鏡下 (油浸レンズ使用，倍率 175 ) で接眼ミクロメー ターを用いて 6 と抢りに区分する。

今成型炭表面に存在する石炭粒子間隔の大きさが. $a, b, c, d, e, f \mathrm{~mm}$ の 6 等級が存在するとする。(こ の際の $a, b \cdots \cdots f$ 注各粒子間隔の平均寸法をもつて 表示する）この 6 とおりの粒子間隔のものが研磨した 成型炭表面にどの程度存在するかを調べるのである が，このためには Fig. 17 に示すとおり，成型炭表 面を 4 等分し，この 4 等分した 3 等分全線上に存在す る 6 等級のそれぞれの粒子間隔の総和（ $a$ については $A \mathrm{~mm}, b \cdots \cdots B \mathrm{~mm}, c \cdots \cdots C \mathrm{~mm}, d \cdots \cdots D \mathrm{~mm}, e \cdots$ $\cdots E \mathrm{~mm}, f \cdots \cdots F \mathrm{~mm}$ ) を積分器により測定し, 成型 炭表面に存在する平均粒子間隔 $(W)$ を次式加算出 する。

$$
W(\mathrm{~mm})=\frac{A+B+C+D+E+F}{\frac{A}{a}+\frac{B}{b}+\frac{C}{c}+\frac{D}{d}+\frac{E}{e}+\frac{F}{f}}
$$




\section{2. 実験結果}

Table 4 の（2）は検鏡の結果で，予想どおり石炭 の成型圧力の高いほど粒子間隔は小さくなることを確 認した。

\section{Tabl 4. Mean space of coal particles in briquette using polarizing microscope method}

(1) Division of space of coal particles which exist in briquette

$\begin{array}{clc}\begin{array}{c}\text { Class of } \\ \text { particle }\end{array} & \begin{array}{l}\text { Space of coal } \\ \text { particle }(\mathrm{mm})\end{array} & \begin{array}{c}\text { Mean space of coa } \\ \text { particle }(\mathrm{mm})\end{array} \\ \text { (1) } & 0 \quad \sim 0.0064 & 0.0032 \\ (2) & 0.0064 \sim 0.0128 & 0.0096 \\ (3) & 0.0128 \sim 0.0256 & 0.0192 \\ (4) & 0.0256 \sim 0.0384 & 0.0320 \\ (5) & 0.0384 \sim 0.0512 & 0.0448 \\ (6) & 0.0512 \sim 0.0640 & 0.0576\end{array}$

\section{III. 成型法と $\boldsymbol{\alpha}$ - ピコリン抽出量}

石炭を乾留する前に, 予め成型するといら処理法が 石炭を乾留するときのコークス化過程における物理的 性状変化にどら影響するかについては前報においての べたが，つぎに石炭のコークス化過程における化学的 性状変化の究明を試みた。

石炭のコークス化過程における化学的性状変化につ いては幾多の研究 114) 125) があるが, 著者は成型炭の コークス化機構究明が目的であるので, それに必要な コークス化過程における化学的特性を考究する方針の もとに, 実験を進めることにした。すなわち成型法と 溶剤抽出量との関係について検討した。

石炭の溶剤抽出量とコークス化性との関係について は 2,3 の研究 ${ }^{126)}$ がすでに報告されている。しかし 石炭を成型したとき成型圧力が溶剤抽出量にどう影響 するかについては全く研究されていない。著者は溶剤 として $\alpha$-ピコリンを選定し，いろいろの条件下にお

(2) Sum total of graduated space of coal particles which exist on trisection lines
Blending ratis of briquette Briquetting
pressure
$\left(\mathrm{kg} / \mathrm{cm}^{2}\right)$ Sum total of graduated mean space of coal particles (mm)
(1) (2)
(3)
(4)
(5) (6)
Mean space of coal particles which exist in briguette ( $\mathrm{mm}$ )

$\begin{array}{cc}\text { Takamatu } & 90 \% \\ \text { coal } & \\ \text { Pitch } & 10 \%\end{array}$

$\begin{array}{llllll}3.10 & 1.50 & 3.69 & 1.76 & 0.69 & 3.95\end{array}$

$\begin{array}{lllllllll}100 & 3.10 & 1.50 & 3.69 & 1.76 & 0.69 & 3.95 & 0.0101 \\ 200 & 3.10 & 2.20 & 2.78 & 2.15 & 0.62 & 3.25 & 0.0095 \\ 300 & 3.62 & 2.35 & 2.17 & 1.33 & 0.76 & 1.46 & 0.0075 \\ 100 & 2.64 & 1.05 & 1.35 & 0.89 & 0.93 & 1.62 & 0.0078 \\ 200 & 2.55 & 1.07 & 0.87 & 0.55 & 0.29 & 2.23 & 0.0075 \\ 300 & 4.01 & 2.62 & 1.57 & 1.10 & 0.55 & 0.67 & 0.0063\end{array}$

ける成型法と $\alpha$ - ピコリン抽出量との関係を吟味した が，特に原料石炭を成型したときにコークス化過程に おける石炭のフムス質部分と粘結成分との反応性の有 無を明らかにすることを目的とした。

1. 試 料

使用した石炭は前述のとおり, 弱粘結炭の大の浦 炭, 田川炭の 2 種, 非粘結炭の高松炭, 中鶴炭, 明治 炭の 3 種, 褐炭の大平洋炭 1 種計 6 種である。この他 これらの試料と比較するため, 現行の装入炭 1 種を加 えた計 7 種である。この装入炭の配合割合は米炭 30 $\%$, カナダ炭 $15 \%$ (以上強粘結炭) 西九州炭 $5 \%$, 豪州炭 $25 \%$ ，筑豊炭 $25 \%$ (以上弱粘結炭) である。 これらの試料原炭の粘結成分量を $\alpha$-ピコリン抽出試 験法 (後述) によつて測定すると, Fig. 18 のごとく

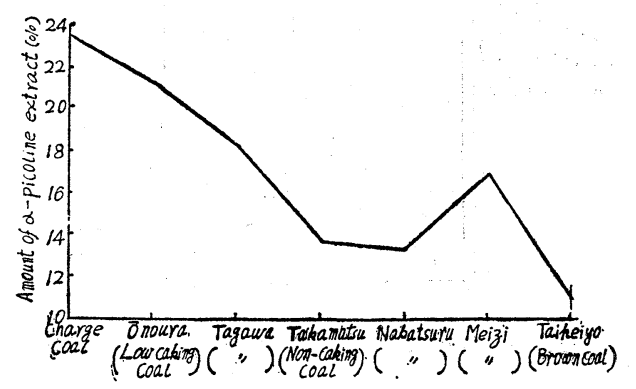

Fig. 18 Amount of $\boldsymbol{\alpha}$-picolin extract of various coals

で, 粘結成分量は装入炭が最も高く, ついで弱粘 結 炭, 非粘結炭, 褐炭の順に少なくなつている。 これらの 7 種石炭はまず乾留試料としてはいずれも 
$1.5 \mathrm{~mm}$ 以下に砕いた後乾燥し，成型しないままでは 粉砕した石炭に水分 $10 \%$ を添加し，よく混合し，成 型炭の場合は装入炭を除く6 種石炭を小型成型機で成 型圧力を $100 \mathrm{~kg} / \mathrm{cm}^{2}, 200 \mathrm{~kg} / \mathrm{cm}^{2}, 300 \mathrm{~kg} / \mathrm{cm}^{2}$ の 3 之 おりに変えて成型炭を製造した。この際の成型炭の寸 法は直径 $30 \mathrm{~mm}$ ，高さ $30 \mathrm{~mm}$ の円筒形である。した がつて乾留用試料は成型しない場合 7 種, 成型炭のと きは 18 種計 25 種である。

このほかフムス質部分の代りに川砂を選び，粘結成 分との反応性を比較検討するための空試験 材料とし た。このため川砂に Fig. 18 に示したそれぞれの石 炭（装入炭を含む）の抽出物を抽出量だけ加え，よく 均一に配合したもの 7 種を準備した。この場合は成型 しないままとした。なおこの際の抽出物は別にそれぞ れの石炭を大型ソックスレー装置によつて抽出を行 い，予め準備しておいた。また川砂は実験に先立つ て, 電気炉で $1,000^{\circ} \mathrm{C}$ ま焼成したものを用い，その 粒度は $1.5 \mathrm{~mm}$ 以下とした。

以上のごとくして，乾留試料は成型しないもの 14 種, 成型炭 18 種合計 32 種となるが，これらをそれぞ れ乾留温度 $200^{\circ} \mathrm{C}, 300^{\circ} \mathrm{C}, 400^{\circ} \mathrm{C}$ および $500^{\circ} \mathrm{C}$ の各 温度で乾留して抽出実験の試料とした。

2. 乾留方法および $\alpha$-ピコリン抽出試験法 上記のごとくして準備した乾留試料 32 種を鉄製円 筒形容器 (寸法值径 $32 \mathrm{~mm}$, 高さ $40 \mathrm{~mm}$ ) に入れ, Fig. 19 に示した乾留炉の中心部に入れ乾留した。

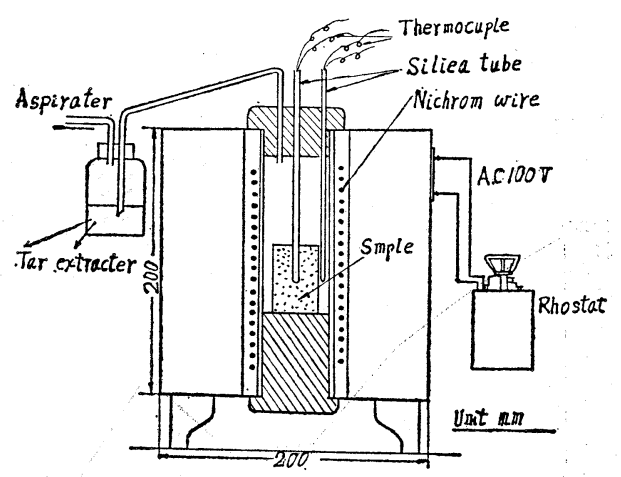

Fig. 19 Bench scale carbonisation furnace

乾留の方法は乾留温度を $200^{\circ} \mathrm{C}, 300^{\circ} \mathrm{C}, 400^{\circ} \mathrm{C}$ およ び $500^{\circ} \mathrm{C}$ の 4 とおりとし, 炉の温度を予め各温度に 上昇せしめておき，直ちに試料の入つている容器をそ れぞれの所定温度で挿入する。かくすると，乾留炉の 温度は急に低下するので，Fig. 19 に掲げたとおり， 試料の中心温度と外側温度をみながら抵抗器により試
料中心温度と外側温度とを希望の温度に急速に上昇せ しめてから，一定時間保定した。なお成型炭では試料 の中心温度を測定しないで, 成型炭上面の温度を測定 したが，予め代表的な $2 ， 3$ の弱粘結炭，非粘結炭を 原料とした成型炭の中心温度と成型炭上面温度とを測 定したところ，中心温度の方が約 $10 \sim 15^{\circ} \mathrm{C}$ 低かつた。 それでこの温度差を加味して, 成型炭の上面温度と外 側温度とをみて乾留温度とした。

かくのごとくして, 各温度で乾留した乾留物は容器 ととともに密閉したかん内に入れ，自然冷却せしめた 後, 取出して 65 mesh 以下に砕き, このらち $5 \mathrm{~g}$ を 採取し, 乾燥後 $\alpha$-ピコリン $300 \mathrm{cc}$ でソックスレー 装置により $50 \mathrm{hr}$ 抽出した。

抽出物はまず蒸留して, $\alpha$-ピコリンの大部分を留 出せしめ, つぎに水蒸気蒸留により $\alpha$-ピコリンをほ とんど完全に追出し, 抽出量を測定した。抽出時間を $50 \mathrm{hr}$ としたのは弱粘結炭, 非粘結炭, 褐炭では上記 抽出条件であれば，ほとんど完全に抽出できることを 予め確めていたからである。しかし約 $45 \%$ の強粘結 炭を含んでいる装入炭の乾留物の場合にはソックスレ 一装置のごとき常圧抽出法では，充分な抽出がおこな われにくいので, 上記ソックスレー装置による抽出を おこなつた後,さらに残りを 50 気圧のオートクレー ブー内で $20 \mathrm{hr}$ 抽出した。なお弱粘結炭についてはン ックスレー装置によつて抽出した残りを同じくオート クレーブによつて抽出試験をおこなつてみたが，ほと んど抽出物は得られなかつた。

3. 乾留温度, 成型圧力と $\alpha$-ピコリン插出量

成型しないときと成型したときの石炭のコークス化 過程における抽出量を吟味する際，まず乾留温度にお ける保定時間が問題となるので，この点を検討した。 つぎに各種試料を対象とし, 乾留温度, 成型圧力と $\alpha$ - ピコリン抽出量の 3 者の関係を系統的に調べた。

\section{（1）乾留温度における保定時間の抽出量に} およぼす影響

前記 6 種石炭のうち, 弱粘結炭の大の浦炭之非粘結 炭の高松炭計 2 種を選んで, 成型しないときと成型圧 力を $100 \mathrm{~kg} / \mathrm{cm}^{2}, 200 \mathrm{~kg} / \mathrm{cm}^{2}$ および $300 \mathrm{~kg} / \mathrm{cm}^{2}$ の 3 と括りで成型した成型炭をそれぞれ乾留温度 $200^{\circ} \mathrm{C}$, $300^{\circ} \mathrm{C}, 400^{\circ} \mathrm{C}$ および $500^{\circ} \mathrm{C}$ で，保定時間を $5 \mathrm{~min}$, $15 \mathrm{~min}, 30 \mathrm{~min}$ の 3 とおりに変えて, 保定時間と $\alpha-$ ピコリン抽出量との関係を調べた。Fig．20にはこれ らの結果を一括してのせた。

これによると, 両試料とも各乾留温度で保定時間を 長くすると, 乾留物の $\alpha$-ピコリン抽出量は低下する 
(1) Ōnoure coal
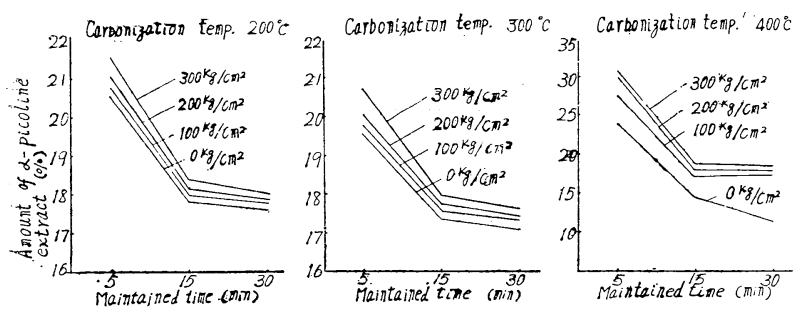

(2) Takamatsu. coal

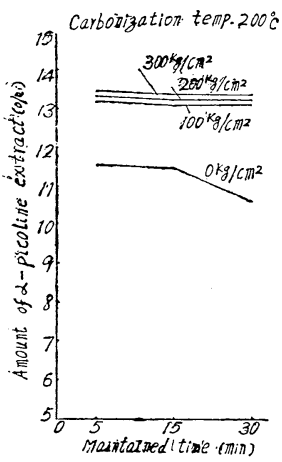

carbonization temp. $3000^{\circ}$
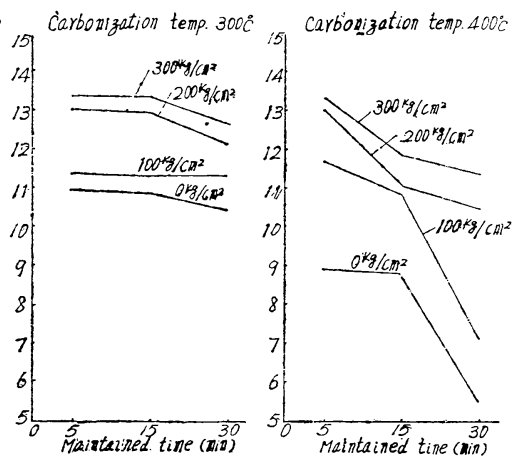

Fig. 20 Relation between the maintained time during coking and the amount of $a$-picoline extract

Fig. 21 より明らかであるように，成型し ない場合では砂と 7 種の石炭(装入炭も含む) の抽出物とを混合した物の乾留物は乾留温度 の上舁とともに抽出量は急に減少している。 これに対して 6 種の石炭試料および装大炭は $300^{\circ} \mathrm{C}$ までは原炭抽出量よりやや減少してい るが，弱粘結炭の大の浦炭および田川炭なら

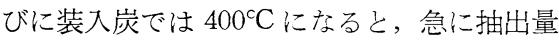
が増し，原炭抽出量よりも若干増加し，特に 装入炭においてはその傾向が顕著となつてい

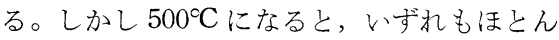
どゼロとなつている。一方非粘結炭, 褐炭で は, $400^{\circ} \mathrm{C}$ でも相変らず抽出量は減少の過程 を辿つている。装入炭, 弱粘結炭が $400^{\circ} \mathrm{C}$ で 急に抽出量が増加し, むしろ原炭抽出物より 増すことは特異の現象である。この現象 $400^{\circ} \mathrm{C}$ において，石炭中のフムス質部分と粘 結成分とが相互に反応して，フムス質部分の 一部を $\alpha$-ピコリンに可溶なる生成物を形成 したものと考えられる。換言すれば，装入炭 および弱粘結炭は, 非粘結炭, 褐炭よりもコ

傾向が認められる。この場合保定時間を $5 \mathrm{~min}$ とした ときが各乾留温度とも抽出量が最も多くなつている。 保定時間を長くすると，抽出物量が少なくなるのは抽 出物が分解するためと思われる。なお Fig. 20 には 乾留温度 $500^{\circ} \mathrm{C}$ の場合を記載しなかつたが，この場合 は両試料とも抽出量はほとんどゼロであつたので省略

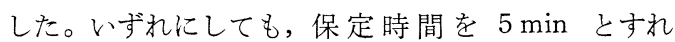
ば，コークス化過程における乾留物の $\alpha$-ピコリン抽 出量の変化を把握するには好都合と思われたので, 以 降の実験においては保定時間を $5 \mathrm{~min}$ とすることに した。なお両試料のコークス化過程における乾留物の 抽出量変化の動きはつぎの項で詳述するので, ここで は省略する。

(2) 成型圧力, 乾留温度と抽出量

Fig. 21 に成型しない場合の前記 14 種の乾留試料 および各成型圧力で成型した成型炭 18 種について乾 留温度 $200^{\circ} \mathrm{C}, 300^{\circ} \mathrm{C}, 400^{\circ} \mathrm{C}$ および $500^{\circ} \mathrm{C}$ でそれぞ れ $5 \mathrm{~min}$ 閒保定して乾留したときの $\alpha$-ピコリン抽 出量の変化を示した。また Fig. 22 は Fig. 21 より コークス化過程において，フムス質部分との反応に関 与した粘結成分量をのせた。この求め方は各温度にお ける石炭の乾留物の $\alpha-$ ピコリン抽出量から粘結成分 と砂との混合物を各温度にて乾留して得た 乾留物の $\alpha$ - ピコリン抽出量を差引いて表示した。
一クス化過程において石炭中のフムス質部分と粘結成 分との反応性が大となり， $\alpha-$ ピコリン可溶のビチュ メン質の生成をみたためであると考えられる。

非粘結炭, 褐炭の場合にはその反応性がかなり劣る ことを意味している。この考えから判断すると, 装入 炭が最もフムス質部分と粘結成分とが有効に反応し, ついで弱粘結炭となり, 非粘結炭, 褐炭はずつと落ち ている。もちろん砂と粘結成分との混合物は砂が不活 性物質であるので，その反応性はほとんど認められな w。

これらの関係を成型炭についてみると, 弱粘結炭, 非粘結炭, 褐炭ともやはり乾留温度 $300^{\circ} \mathrm{C}$ ま 量は減少するが，その減少度合は成型しないときより も少くなつている。しかし $400^{\circ} \mathrm{C}$ にると, いずれの 試料も $300^{\circ} \mathrm{C}$ のとよりも急に抽出量が増加し, その 傾向は成型炭の成型圧力が大になるにつれて増してい る。特に成型しないときは非粘結炭, 褐炭では, この 現象が全然表われず, 成型炭に打いて初めて現出して いる。特に弱粘結炭でも成型圧力が $200 \sim 300 \mathrm{~kg} / \mathrm{cm}^{2}$ の場合には，成型しないときの装入炭程度に接近し，

あるいはそれ以上になることを確認した。

非粘結炭, 褐炭では弱粘結炭に較べると， $400^{\circ} \mathrm{C}$ に おける乾留物の抽出量はかなり劣つているが，これら も弱粘結炭と混炭し, 成型圧力 $200 \sim 300 \mathrm{~kg} / \mathrm{cm}^{2}$ で成 

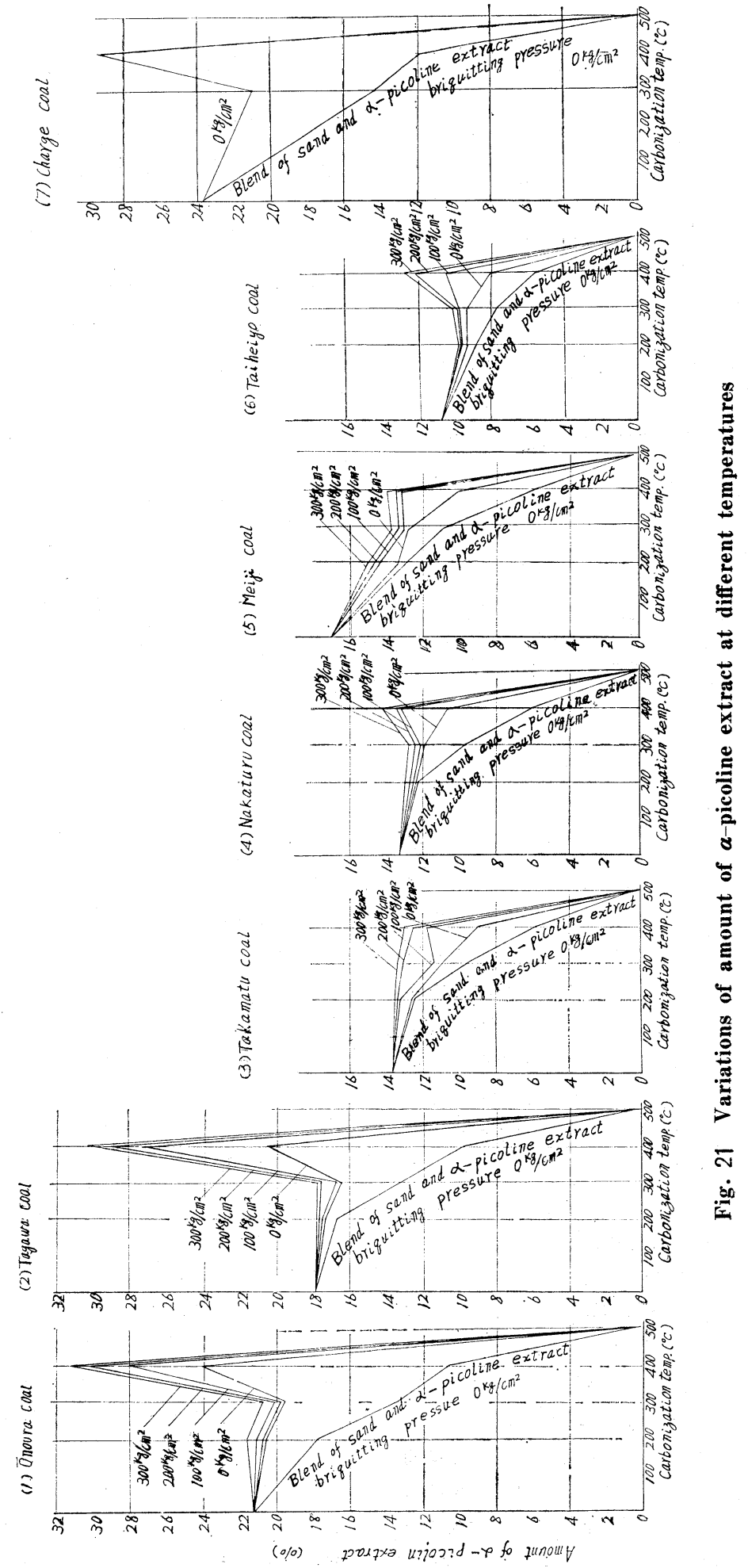

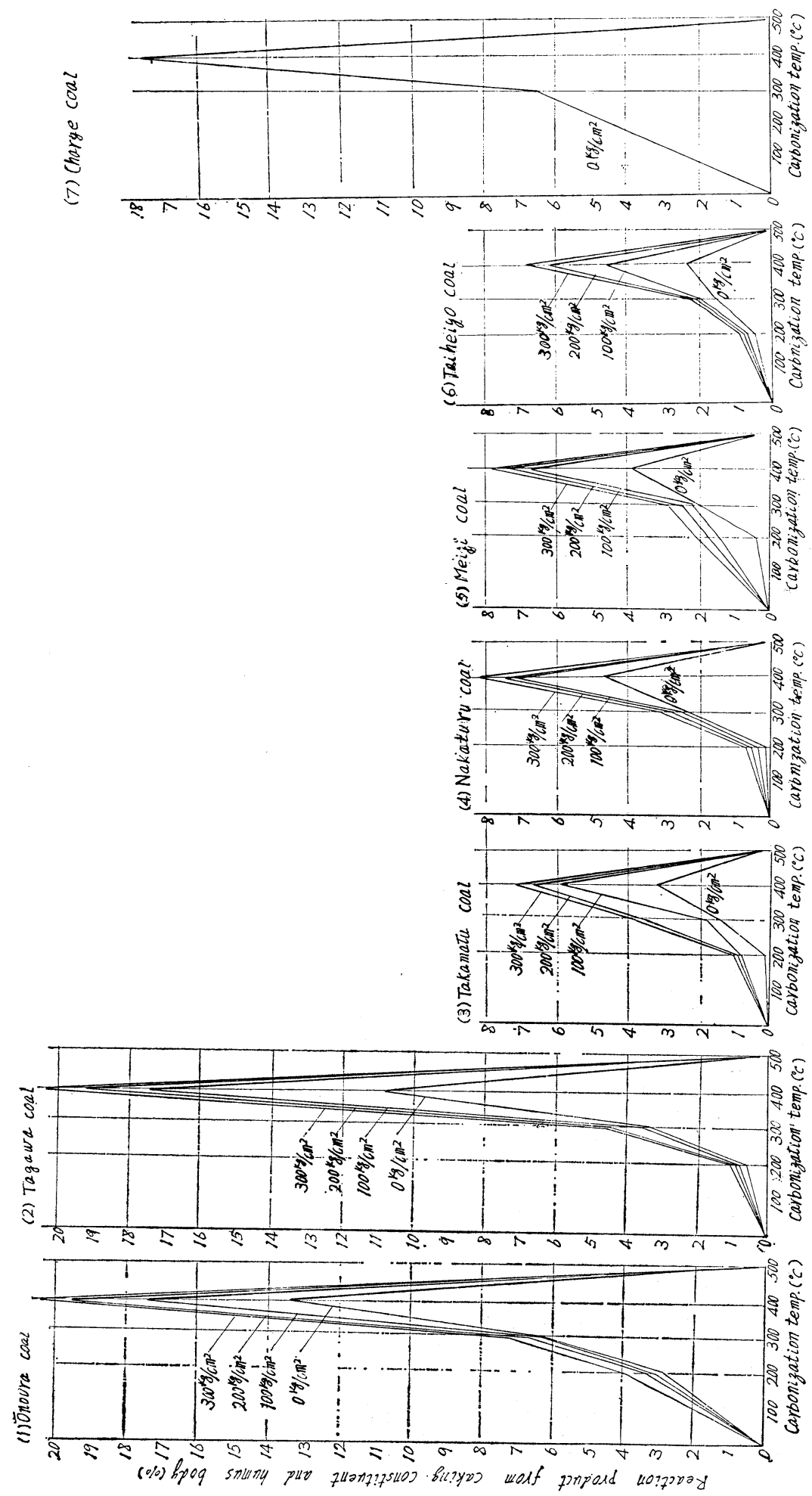
型すれば, 成型しないときの装入炭程度の抽出量に接 近せしめることが可能と思われる。換言すれば，上記 成型圧力で成型した成型炭はコークス化過程におい て, フムス質部分と粘結成分との反応度が進み, その 結果よいコークスがえられるものと解釈される。なお 砂と石炭抽出物との混合物について, 成型の効果を検 討するため, 砂と大の浦炭原炭抽出物を対象とし, 成 型圧力を $300 \mathrm{~kg} / \mathrm{cm}^{2}$ として, 乾留温度を $200^{\circ} \mathrm{C}, 300$ ${ }^{\circ} \mathrm{C}, 400^{\circ} \mathrm{C}$ および $500^{\circ} \mathrm{C}$ とし, 各温度における乾留 物の抽出量を調べたところ, Table 5 のとおりであつ た。

Table 5 Change of amount of extract for blends of sand and extract under briquetting and no-briquetting at different temperatures

\begin{tabular}{ccccc}
$\begin{array}{c}\text { Briquetting } \\
\text { pressure } \\
\left(\mathrm{kg} / \mathrm{cm}^{2}\right)\end{array}$ & \multicolumn{4}{c}{$\begin{array}{c}\text { Amount of extract at different } \\
\text { temperatures }(\%)\end{array}$} \\
\cline { 2 - 5 } 0 & $200^{\circ} \mathrm{C}$ & $300^{\circ} \mathrm{C}$ & $400^{\circ} \mathrm{C}$ & $500^{\circ} \mathrm{C}$ \\
300 & 17.7 & 13.4 & 10.6 & 0.3 \\
& 18.1 & 13.8 & 11.2 & 0.3
\end{tabular}

これをみて明らかであるように, 砂と石炭抽出物と の混合物関しては成型の効果は注とんど認められな 的。

以上のごとくして, 弱粘結炭と非粘結炭あるいは弱 粘結炭と褐炭とを適正に配合したものを原料とし, 成 型圧力 $200 \sim 300 \mathrm{~kg} / \mathrm{cm}^{2}$ で成型し乾留すれば, この際 のコークス化過程に扔けるフムス質部分と粘結成分と の反応性が通常の場合における強粘結炭を相当に含ん でいる装入炭中のフムス質部分と粘結成分との反応性 程度まで向上するのが認められる。この事実は石炭を 加圧成型する手段がコークス化過程において，フムス 質部分と粘結成分との相互作用度を高め, 石炭粒子の 粘結作用を有効ならしめるとみてよからう。

（3）乾留温度 $400^{\circ} \mathrm{C}$ における乾留物の抽出量 増加原因

上記のとおり, 弱粘結炭, 非粘結炭, 褐炭の成型炭 《乾留温度 $400^{\circ} \mathrm{C}$ で乾留すると, 乾留物の $\alpha$-ピコリ ン抽出量が急に増加し, しかも増加の度合は成型圧力 の大なるほど高いことが判明した。この原因について 考察する。

乾留温度 $400^{\circ} \mathrm{C}$ で $\alpha$-ピコリン抽出量の増加したこ と, Fig. 22 に示すフムス質部分と粘結成分との反応 性が増加することから考えて, $400^{\circ} \mathrm{C}$ 付近の温度で は, フムス質部分の一部が粘結成分と反応し, 溶剤に

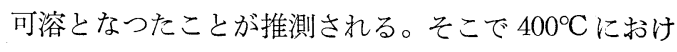
る乾留物の $\alpha$-ピコリン抽出物中に含まれる成分につ いて検討を加えた。

試料は Fig. 21 に揭げた大の浦炭（弱粘）と高松炭 （非粘）の 2 種について成型しないときと各成型圧力 で成型した場合の乾留温度 $400^{\circ} \mathrm{C}$ での乾留物の $\alpha-ヒ^{\circ}$ コリン抽出物をそのまま用いた。抽出物中の $\beta, \gamma$ の 含有量定量法はこれまで採用されているクロロホルム 抽出法 ${ }^{1271128)}$ によつた。

すなわちまず抽出物を 65 mesh 以下に砕いたもの を乾燥し, このうち $3 \mathrm{~g}$ を採り, 溶剤のクロロホルム $300 \mathrm{cc}$ で 50 時間ソックスレー装置により抽出した。 クロロホルムに可溶物は $\gamma$ 成分で, 不溶解物は $\beta$ 成 分となる。Fig. 23 に $3, \gamma$ 両成分の含有量を揭げた。

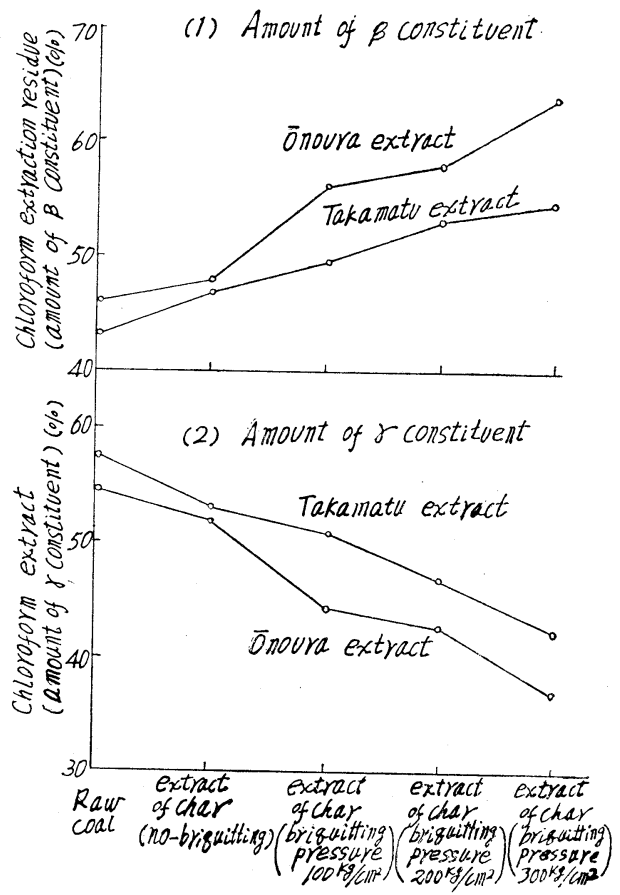

Fig. 23 Changes of amount of $\beta$ and $\gamma$ constituent contained in $\alpha$-picolin extract

これによると, 両試料の抽出物中の $\beta$ 含有量で は, 成型しないときよりも成型炭の方が多くなり, 成 型炭では成型圧力の増すにつれて漸増している。これ に対して, $\gamma$ 含有量は $\beta$ 含有量と対称的に減少する 傾向を示している。

石炭抽出物中の $\beta$ 成分はもともとフムス質部分の 変化したものといわれているので，129～133) 成型しな 
いときよりも成型炭乾留物の抽出物中に $\beta$ 含有量が 多いことは成型することにより，コークス化過程中， 石炭のフムス質部分と粘結成分との反応により，フム 不質の一部が $\beta$ 成分類似物に変質し， $\alpha-$ ピコリン による抽出量の増加を招来するものと考える。

なお前報で論述したごとく, 石炭を加圧成型すれ ば,コークス化過程において成型しない場合に較べ て, $400 \sim 450^{\circ} \mathrm{C}$ 間の石炭の軟化溶融時の粘結作用が 助長されていることを確めた。この事実はこれまで, しばしばのべたと扔り, 乾留温度 $400^{\circ} \mathrm{C}$ 付近における

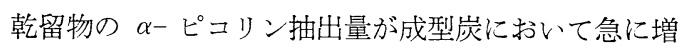
すこともよく符合する現象である。

すなわち石炭を加圧成型すれば, コークス化時に粘 結作用が助長されるが, 助長の意味は成型によつて石 炭粒子間隔が狭まり, そのため石炭の粘結成分が粘結 作用に有効に活用されるとともに，加熱によりビチュ 一メン質とフムス質との反応性の増大をきたし，これ が粘結作用に大きく寄与することである。

\section{IV. 抽出物の性状}

前記のごとく, コークス化過程における各種石炭の $\alpha$-ピコリン抽出量の変化を一応把握することができ た。それで今度はコークス化過程において, 最もコー クス化性を支配する乾留温度 $400^{\circ} \mathrm{C}$ における各種石炭 の成型しないときと成型炭乾留物の $\alpha$-ピコリン抽出 物の性状がどのように相違しているかをいろいろの角 度から調べた。

\section{1. 試料およびその性状測定法}

試料は前記 6 種石炭の成型しないものおよび各成型 圧力での成型炭をそれぞれ乾留温度 $4400^{\circ} \mathrm{C}$ で 5 分間保 定して乾留した乾留物の $\alpha$-ピコリン抽出物 24 種な らびに同じく現行溶鉱炉用コークス製造原料炭を通常 の状態のままで $400^{\circ} \mathrm{C} て ゙ 5$ 分間保定したときの乾留物 の抽出物 1 種と参考のためにそれぞれの原炭の抽出物 6 種を加えた合計 31 種である。

これらの 31 種抽出物について, 工業分析, 元素分 析, 真比重, 粘性, 粘結力および芳香族炭素, 環縮合 度を調べた。工業分析, 元素分析, 真比重は J I S 法, 粘結力は第 1 章でのべた方法, 粘性, 芳香族炭 素, 環縮合度は下記方法により測定した。

（1）粘 性

石炭の粘性変化を調べる方法にはこれまで 2,3 の 方法が提案されているが，134) 143) 今次試験ではわが 国に一般に採用されている Gieseler Plastometer を 採用した。本装置による測定法は寸でに結介済みであ るが，144)145) その大要をのべると，下記のごとくであ
る。Fig. 24 に本装置の外観を示す。

まず乾懆試料を $35 \mathrm{mesh}$ 以下に粉砕したもの $4 \mathrm{~g}$ を 採り、レトルトにかきまぜ棒とともに入れる。つぎに 試料の入つたレトルトとかきまぜ棒とを Fig. 24 の右 側に示す加圧装置に移し，10kg の荷重を載せ 15 分間 加圧する。その後このようにして加圧されたものを電 気炉内のメタルバスに挿入する。このときバスの温度

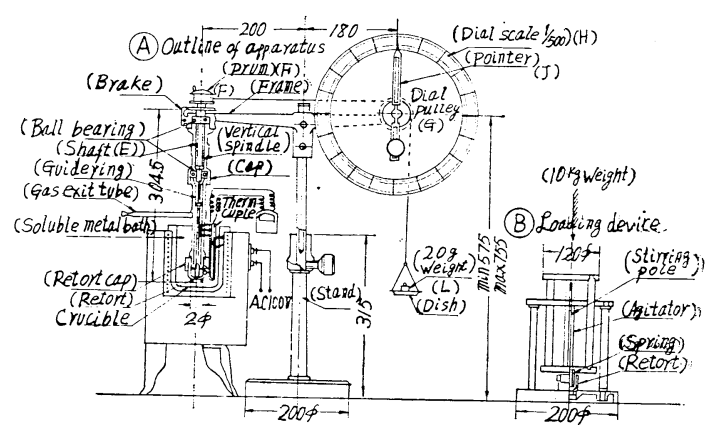

Fig. 24 Gieseler-type plastometer

は予め約 $200^{\circ} \mathrm{C}$ 付近に上昇せしめてあるので, 試料挿 入と同時に急に約 $150^{\circ} \mathrm{C}$ 位に低下する。以後は $3^{\circ} \mathrm{C} /$ $\min$ の加熱速度で温度を上昇せしめると, 温度の上昇 とともに試料が軟化するので, 打もり（I）の力で, シャフト $(\mathrm{E})$, ドラム $(\mathrm{F})$, ダイアルプーリー $(\mathrm{G})$, がともに迴転する。そのため (G) に固定されたダイ アルスケール $(\mathrm{H})$ 上の指針（J）が動き始める。そ れで1分間ごとにダイアルゲージを読む。

かくすると, 軟化開始温度, 溶融温度, 最高流動 度, 固化温度, 軟化溶融温度範囲はつぎのごとく決定 される。

I ) 軟化開始温度……指針が移動し始めたときの温. 度。

II) 溶融温 度……指針が動き始めてから次第に 動きが増加する途中において 1 分間 50Division に達した ときの温度。

III) 最高流動度……指針が 1 分間最も多く移動し たときの温度を最高流動度初; 点とし，そのときの 1 分間の Division をもつて最高流動度 とみなす。

IV) 固 化 温 度……指針の動きが次第に減少する 途上, 1 分間 50Division に なつたときの温度。 
V) 軟化溶融温度……溶融温度から固化温度までの 温度範囲。

なおコークス用炭では軟化開始温度, 固化温度が高 く，かつ最高流動度の高いものほど良質石炭である。

以上が粘性の測定方法の大要であるが，今次試験で 蛙抽出物自身については測定しないで，大の浦炭を基 炭とし，これに前記試料の抽出物 $10 \%$ を配合したと きの粘性を測定した。

(2) 芳香族炭素および環縮合度

石炭およびピッチ重合物中の芳香族炭素および環縮 合度を決定する方法として D. W. van Krevelen 氏 146)1477 はこれら物質の元素分析值および真比重より算
出する方法を提案しているので，この方法に準 拠し た。

その大要はつぎのとおりである。まず元素分析值 $(G, H, N, S, O)$ 上り $H / C, N / C, S / C, O / C$ の原子 比を求め, これらと真比重 $(D)$ および炭素原子当り の芳香族環の数 $(R / C)$ との関係を求めると

$$
\begin{array}{r}
\frac{1}{D}=\frac{9.9+3.1 H / C+3.35 O / C+1.5 N / C}{12.01+1.008 H / C+16 O / C} \\
\cdot \frac{+14 S / C-(9.1-3.65 H / C) R / C}{+14 N / C}
\end{array}
$$

となる。したがつて $R / C$ が判明するので, 芳香族炭 素の割合 $\left(F_{a}\right)$ 注次記式で示される。
Kinds of coal

Ōnoura coal
(Low-caking coal)
(Low-caking coal)

Takamatu coal (Non-caking coal)

Nakaturu coal (Non-caking coal)

Meizi coal
(Non-caking coal)

Taiheiyo coal (Broun coal)

Charge coal
Briquetting pressure

$$
\left(\mathrm{kg} / \mathrm{cm}^{2}\right)
$$

Extract of raw-coal

No briquetting

100
200
300

Extract of raw-coal No briquetting 100 200 300

Extract of raw-coal No briquetting

100
200
300

Extract of raw-coal No briquetting

$$
\begin{aligned}
& 100 \\
& 200 \\
& 300
\end{aligned}
$$

Extract of raw-coal

No briquetting

100
200
300

Extract of raw-coal No briquetting

100
200
300

No briquetting

Table 6 Characteristics of

Ultimate analysis (d.a.f)

(\%)

\begin{tabular}{ccccc}
\hline$C$ & $H$ & $N$ & $S$ & $O$ \\
83.73 & 6.63 & 1.23 & 0.45 & 7.96 \\
83.35 & 6.49 & 1.37 & 0.36 & 8.46 \\
83.88 & 6.34 & 1.39 & 0.37 & 8.02 \\
83.10 & 6.30 & 1.42 & 0.33 & 8.85 \\
83.35 & 6.33 & 1.43 & 0.33 & 8.56 \\
82.28 & 6.85 & 1.67 & 0.39 & 8.81 \\
82.11 & 6.30 & 1.34 & 0.33 & 9.92 \\
82.33 & 6.36 & 1.38 & 0.35 & 9.58 \\
82.11 & 6.28 & 1.51 & 0.32 & 9.78 \\
82.07 & 6.24 & 1.48 & 0.30 & 9.91 \\
81.64 & 7.03 & 1.29 & 0.50 & 9.54 \\
82.30 & 6.37 & 1.56 & 0.33 & 9.44 \\
81.84 & 6.35 & 1.54 & 0.35 & 9.92 \\
82.60 & 6.35 & 1.62 & 0.32 & 9.11 \\
82.63 & 5.90 & 1.66 & 0.30 & 9.51 \\
80.75 & 6.90 & 1.31 & 0.51 & 10.51 \\
80.58 & 6.19 & 1.61 & 0.54 & 11.06 \\
79.88 & 6.17 & 1.65 & 0.43 & 11.87 \\
79.46 & 6.19 & 1.67 & 0.44 & 12.24 \\
80.45 & 6.15 & 1.69 & 0.41 & 12.30 \\
82.10 & 6.51 & 1.78 & 0.81 & 8.80 \\
81.30 & 6.21 & 1.34 & 0.80 & 10.35 \\
81.27 & 6.05 & 1.32 & 0.81 & 10.55 \\
79.28 & 6.00 & 1.45 & 0.78 & 12.49 \\
79.73 & 5.94 & 1.48 & 0.71 & 12.44 \\
81.72 & 7.40 & 1.15 & 0.54 & 9.19 \\
80.06 & 6.78 & 1.44 & 0.32 & 11.41 \\
80.02 & 6.76 & 1.32 & 0.29 & 11.61 \\
79.97 & 6.70 & 1.27 & 0.23 & 11.73 \\
79.61 & 6.68 & 1.28 & 0.25 & 12.08 \\
81.53 & 5.31 & - & 0.61 & -
\end{tabular}


また環縮合度 $\left[\frac{2(R-1)}{C}\right]$ は芳香族炭素の割 合が （1）式から判明するので，次式により算出す。

$$
\frac{2(R-1)}{C}=2-F_{a}-\frac{H}{C}
$$

かくして抽出物の元素分析，真比重が判明すれば, (1), (2) 式から芳香族炭素および環縮合度が算出でき る。

2. 結 果

Table 6 には前記 6 種の原炭抽出物と成型しないも

$$
F_{a}=\left(1-\frac{H}{C}\right)+\left(1-\frac{2 R}{C}\right)
$$

のと各種成型圧力での成型炭とをそれぞれ $400^{\circ} \mathrm{C}$ で乾 留したときの乾留物の $\alpha$-ピコリン抽出物について性 状を一括してのせた。

また Table 7 には大の浦炭を基炭として，これに つぎに記する $\alpha$-ピコリン抽出物 II， III，IV をそれ ぞれ $10 \%$ ずつ混合して，加熱した場合の粘性試験結 果を示した。

II ……原炭の抽出物。

III……成型しないで， $400^{\circ} \mathrm{C}$ で乾留したものの抽 出物。

IV ……成型圧力 $200 \mathrm{~kg} / \mathrm{cm}^{2}$ で成型して $400^{\circ} \mathrm{C}$ で 乾留したものの抽出物。

\begin{tabular}{|c|c|c|c|c|c|c|c|c|}
\hline $\mathrm{H} / \mathrm{C}$ & $N / C$ & $S / C$ & $O / C$ & $\begin{array}{c}V . M \\
(\%)\end{array}$ & $\begin{array}{l}\text { Specific } \\
\text { gravity }\end{array}$ & $\begin{array}{l}\text { Caking } \\
\text { power } \\
(\%)\end{array}$ & $\begin{array}{l}\text { Aroma- } \\
\text { ticity } \\
\quad\left(F_{a}\right)\end{array}$ & $\begin{array}{l}\text { Ring condens- } \\
\text { ation index } \\
\left(\frac{2(R-1)}{C}\right)\end{array}$ \\
\hline 0.943 & 0.013 & 0.002 & 0.071 & - & 1,166 & 92.9 & 0.743 & 0.314 \\
\hline 0.934 & 0.014 & 0.002 & 0.079 & 57.4 & 1,170 & 93.7 & 0.776 & 0.290 \\
\hline 0.901 & 0.014 & 0.002 & 0.075 & 54.9 & 1,178 & 93.7 & 0.779 & 0.300 \\
\hline 0.888 & 0.015 & 0.001 & 0.080 & 53.7 & 1,181 & 94.1 & 0.838 & 0.274 \\
\hline 0.904 & 0.015 & 0.001 & 0.077 & 52.7 & 1,185 & 94.1 & 0.784 & 0.312 \\
\hline 0.992 & 0.017 & 0.001 & 0.080 & & 1,169 & 92.7 & 0.684 & 0.324 \\
\hline 0.914 & 0.014 & 0.002 & 0.091 & 57.3 & 1,181 & 93.2 & 0.796 & 0.285 \\
\hline 0.920 & 0.014 & 0.002 & 0.087 & 55.8 & 1,182 & 93.8 & 0.788 & 0.292 \\
\hline 0.911 & 0.016 & 0.001 & 0.089 & 54.2 & 1,185 & 93.8 & 0.813 & 0.276 \\
\hline 0.895 & 0.015 & 0.001 & 0.081 & 53.1 & 1,190 & 93.9 & 0.797 & 0.308 \\
\hline 1.026 & 0.014 & 0.002 & 0.088 & & 1,150 & 93.0 & 0.696 & 0.278 \\
\hline 0.922 & 0.016 & 0.002 & 0.086 & 65.0 & 1,165 & 93.3 & 0.840 & 0.228 \\
\hline 0.924 & 0.016 & 0.002 & 0.091 & 64.5 & 1,175 & 93.3 & 0.826 & 0.250 \\
\hline 0.916 & 0.017 & 0.002 & 0.083 & 64.4 & 1,181 & 93.9 & 0.796 & 0.288 \\
\hline 0.851 & 0.017 & 0.002 & 0.086 & 60.2 & 1,192 & 93.8 & 0.893 & 0.256 \\
\hline 1.018 & 0.014 & 0.002 & 0.098 & & 1,163 & 92.4 & 0.704 & 0.278 \\
\hline 0.920 & 0.017 & 0.003 & 0.103 & 63.1 & 1,174 & 93.4 & 0.878 & 0.202 \\
\hline 0.920 & 0.018 & 0.002 & 0.112 & 62.5 & 1,176 & 93.4 & 0.910 & 0.176 \\
\hline 0.923 & 0.018 & 0.002 & 0.116 & 60.8 & 1,178 & 93.7 & 0.911 & 0.166 \\
\hline 0.910 & 0.018 & 0.002 & 0.115 & 58.5 & 1,185 & 93.8 & 0.906 & 0.184 \\
\hline 0.945 & 0.019 & 0.004 & 0.080 & & 1,164 & 92.4 & 0.789 & 0.266 \\
\hline 0.910 & 0.014 & 0.004 & 0.096 & 61.5 & 1,170 & 94.4 & 0.872 & 0.218 \\
\hline 0.915 & 0.014 & 0.004 & 0.097 & 60.8 & 1,172 & 94.4 & 0.859 & 0.226 \\
\hline 0.906 & 0.016 & 0.004 & 0.118 & 57.7 & 1,178 & 94.5 & 0.932 & 0.162 \\
\hline 0.887 & 0.016 & 0.003 & 0.117 & 57.4 & 1,189 & 94.5 & 0.929 & 0.184 \\
\hline 1.079 & 0.012 & 0.002 & 0.084 & & 1,159 & 92.7 & 0.533 & 0.388 \\
\hline 1.008 & 0.015 & 0.001 & 0.107 & 64.2 & 1,162 & 93.9 & 0.770 & 0.222 \\
\hline 1.006 & 0.014 & 0.001 & 0.109 & 62.5 & 1,171 & 94.0 & 0.742 & 0.252 \\
\hline 1.001 & 0.014 & 0.001 & 0.110 & 61.0 & 1,172 & 94.1 & 0.789 & 0.210 \\
\hline 1.007 & 0.014 & 0.001 & 0.114 & 58.8 & 1,179 & 94.1 & 0.727 & 0.266 \\
\hline 0.782 & - & 0.003 & - & 54.3 & - & 93.8 & - & - \\
\hline
\end{tabular}

\section{$\alpha$-picoline extract}




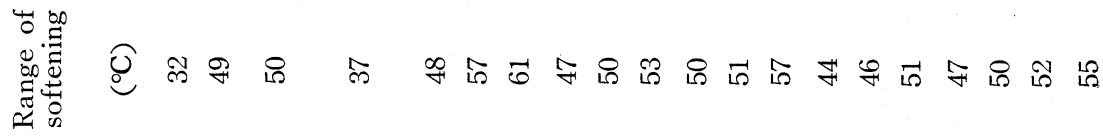

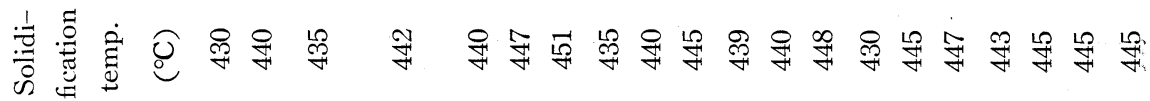

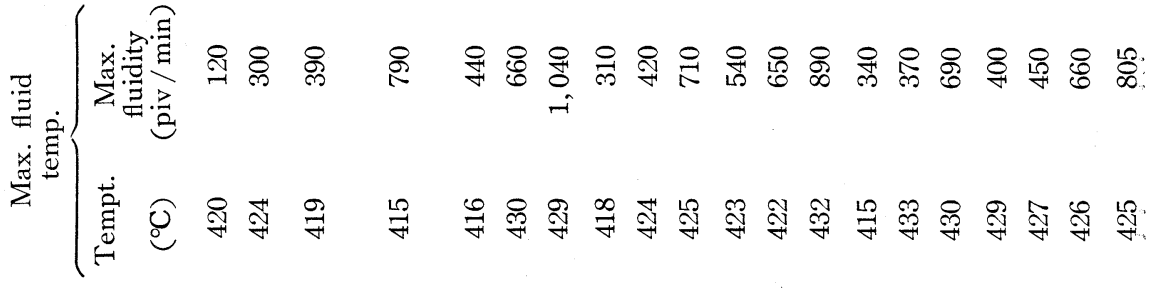

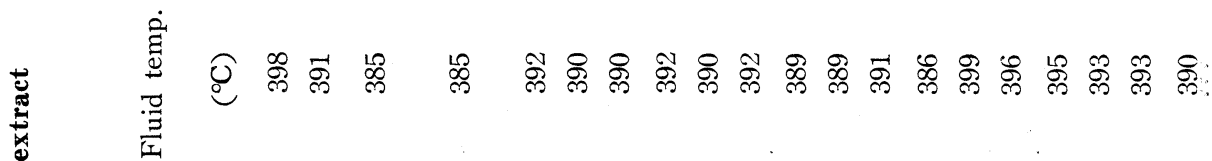

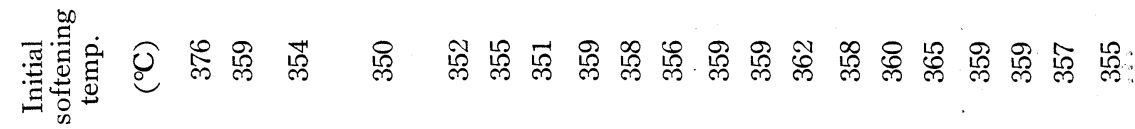

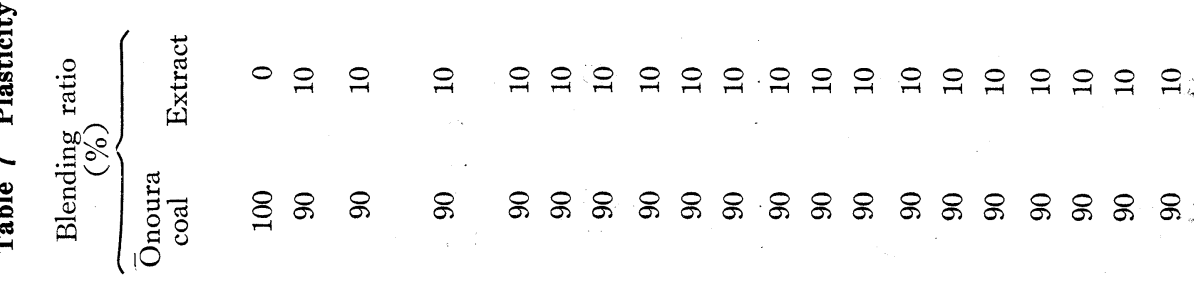

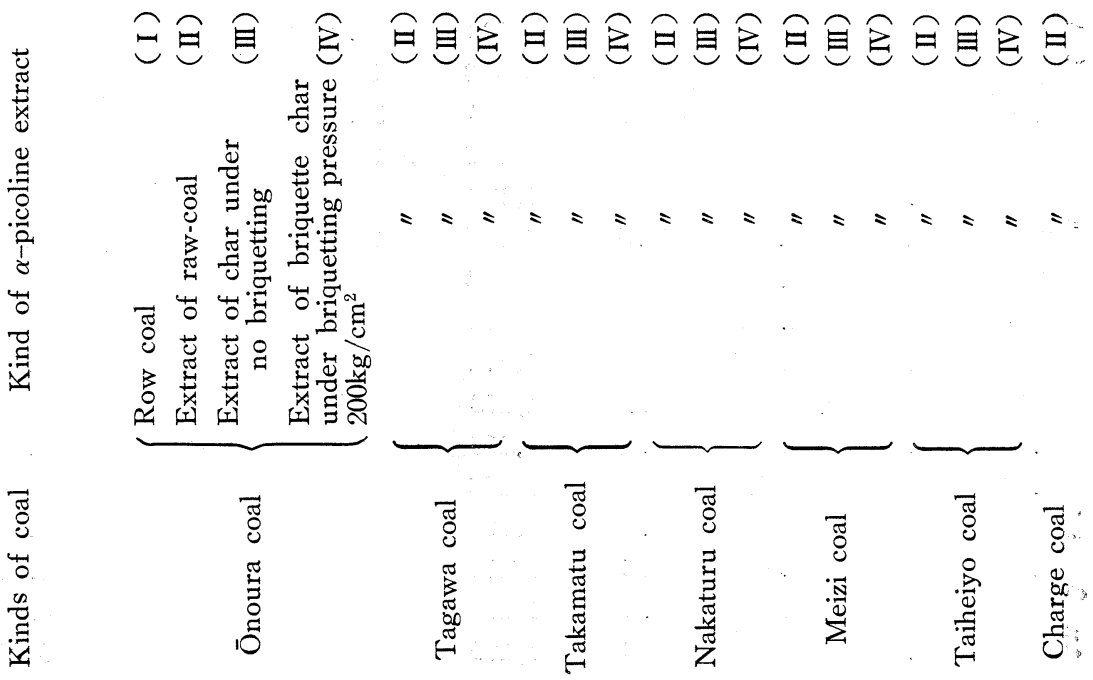


なお参考のために, Table 6 および Table 7 とも 成型しない装入炭を $400{ }^{\circ} \mathrm{C}$ で乾留した乾留物の性状を も同時にのせた。

（1）粘結力および粘性

粘結力指数ではいずれの試料についても加圧しない ときと成型したときとは同程度で，両者間には差異は ほとんどなく，かつ試料炭種別による粘結力指数の相 違も認められない。しかし Table 7 に揭げた粘性に おいては成型しないときと成型した場合の抽出物で は, 後の方がいずれの試料のときも軟化温度範囲が長 く, かつ最高流動度もかなり高为となつている。

コークス化過程にお注粘性の性状としては軟化溶 融温度範囲が長く, 最高流動度が高いものほど粘結作 用が良好となるといわれている。この点からすると， 成型炭乾留物の抽出物は粘結作用の面ですぐれている と判断される。

（2）芳香族炭素および環縮合度

Table 6 に示すと扔り, 成型しないときと成型炭を 乾留したときでは乾留物の抽出物中の芳香族炭素はほ とんぞの場合, 成型炭の方がやや多くなつている。し かしその差はきわめて僅少である。一方環縮合度は弱 粘結炭执よび褐炭のときはわずか汇高くなる傾向を示 しているが，非粘結炭では反対に減少している向きが ある。ただしこれらの傾向は明確に差が存在するとい いきれるほどでない。要するに成型したときと，しな いときで $400^{\circ} \mathrm{C}$ に扔汀乾留物の抽出物についての芳 香族炭素拉よび環縮合度からはこれらの抽出物性状判 定は困難のよらである。

総括すると，成型炭乾留物が成型しないときに較べ て性状が一番大きく相異したのは成型炭乾留物の抽出 物粘性が成型しないときの抽出物の粘性より秀れ, 粘 結作用の面で期待が寄せられることである。成型した 場合, 乾留物の抽出物の粘性は弱粘結炭, 非粘結炭お よび蝎炭のうち, 弱粘結炭の場合が一番よく, 褐炭の ときが劣つている。しかして弱粘結炭の成型炭乾留物 の抽出物の粘性に強粘結炭を相当含んでいる現在の装 入炭を成型しないで $400^{\circ} \mathrm{C} て ゙$ 乾留したときの乾留物の 抽出物の粘性程度まで向上している。

\section{$\mathrm{V}$. 成型炭のコークス化機構についての考察}

成型炭のコークス化過程におけるコークス化性機構 究明を究極の目的として, 前報㧍よび本報で, 諸般の 実験を重㸚た。これらの結果に基づいて, 成型炭のコ 一クス化機構について考察を加えてみる。石炭を加圧 成型して成型炭とすると, 成型しないときに較べて本 報（II）でのべたごとく石炭粒子間隔が小となり, こ
れに関連してつぎの現象を認めることができた。

（1）前報の（IIの 2）にみるとおり, 原料石炭を 成型しないときよりも成型した方が原料石炭の粘結力 指数はかなり向上する。

（2）前報の（IIIの1）においてのべたとおり，コ 一クス化過程の $400 \sim 450^{\circ} \mathrm{C}$ 付近の溶融帯において原 料石炭を成型するときとしないにきとでは異なる現象 を示した。すなわちこの時期における原料石炭の収縮 量は成型したときは成型しないときに較べて原料石炭 の収縮量が減少した。この収縮量の減少はコークスに 発生する割れめ防止の意味からも好ましい。また前報 の（IIIの 2) で成型炭のコークス化過程における原料 石炭の分解温度は成型したときがしない場合より熱分 解に対する抵抗が大となつてきている。このこともコ 一クス化性の立場からすると, 一つの有利な現象とみ なされる。

（3）さらに重要な現象としては本報の（III）およ び（IV）でのべたと㧍り，成型炭をコークス化する と, コークス過程を通じて石炭中のフムス質部分と粘 結成分との反応性が増大してきて, その結果フムス質 部分の一部が溶剤可溶物質に変質してくることであ る。しかしその結果として，この反応性の増加はコー クス化過程における原料炭の粘結力助長と粘結成分の 質をも好ましい状態に改善していることが認められ た。

原料石炭を加圧成型することにともなら，これらの 諸現象は石炭のコークス化性の立場からすると，石炭 のコークス化性が加圧成型によつて好ましい方向に進 展しているとみなして差支充るるい。なおこれらの 現象は成型圧力の増大につれて, ますますよい方向に 進むことも確認された。

要するに石炭を成型すると, 石炭の粒子間隔が小と なることが因となり，コークス化過程において上述の (2)，(3)の現象, 特に（3）の現象が起り, コークス 化現象は成型圧力の増大に比例して, ますます有利に 進展し, 結果として良質の成型コークスが, コークス 化性の劣る石炭からも製造することができるものと考 えられる。

\section{VI. 結 論}

成型炭のコークス化機構を究明するため成型炭の成

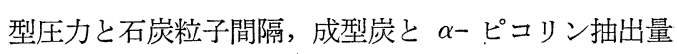
および $\alpha$-ピコリンによる抽出物の性状を検討し, 成 型炭のコークス化性機構を積明し，つぎの点を明らか にした。

（1）E. Daub 氏の検鏡試験による方法を用いて， 
成型炭の粒子間隔を定量的に測定したところ，成型圧 力が大となると平均粒子間隔は小となることをはつき り認めた。

（2）石炭を乾留するとき $200 \sim 500^{\circ} \mathrm{C}$ 間における 乾留物について $\alpha$-ピコリンによる抽出試験をおこな つた。その結果特異な現象として $400^{\circ} \mathrm{C}$ 防近における 乾留物についての抽出量が，石炭を成型して成型炭と したときとしない場合とでは相当汇相違し，成型炭の 方が $\alpha$-ピコリンによる抽出量は増大し，この傾向 は成型圧力が大となるにつれて増加することが判明し

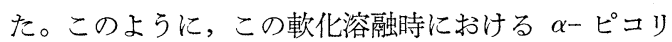
ン抽出量は成型した場合が成型しないとに較べて増す のは石炭中のフムス質部分と粘結成分とがコークス化

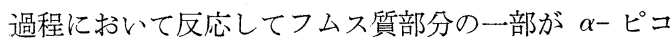
リン可溶の生成物になると考え，コークス化過程にお けるフムス質部分と粘結成分との反応性を吟味した結 果, 成型炭においてはこの反応性は成型圧力の増大に つれて大となることを確めた。

(3) さらに抽出物組成の, 化学組成, 芳香族炭 素, 環縮合度および物理的粘性の面を比較検討した。 その結果成型炭の場合の抽出物が質の点でも若干寸ぐ れていることが認められた。すなわち石炭を成型すれ 代，石炭のコークス化性に重要な役割を果す石炭の粘 結成分が成型しないときよりも量, 質とも有利な方向 に進展し, 成型炭のコークス化性がこの面からもよく なることを認めた。

（4）以上の結果を考察し, 成型炭のコークス化機 構をつぎのごとく推定した。

石炭を成型炭とすると, 成型しないとに較べて石炭 粒子間隔は小となる。これ自身でも石炭粒子間の粘結 作用は大となるが，石炭粒子間隔が小となつた結果， 石炭のフムス質部分と粘結成分とのコークス化過程に おける反応性が大となり，その結果としてフムス質部 分の一部が粘結成分に変質して粘結成分の増量をきた すのみならず，その質をも改善され，乾留温度 $400^{\circ} \mathrm{C}$ 附近の軟化溶融時における粘結成分の粘結作用がより 助長され, 生成コークスの質が著しく改善されると解 勫される。これらのことからしてコークス化性の劣る 石炭から良質成型コークスが製造できると考えた。

\section{附 記}

本研究の遂行に当りいろいると御助言および御指導 を賜わつた前九大工学博士加藤常太郎教授, 九大工学 博士田中武英教授, および工学博士竹下健次郎教授に 深謝の意を表するとともに直接御指導下さつた当所コ 一クス研積室長工学博士城博氏に深く感謝するしだい
であります。

\section{文献}

112) H. Freund; Handbuch der Mikroskopie in der Technik, 2, 340 342 (1952)

113）高橋良平, 炭研, 9, 265, 昭 33

114) K. Bunte and H. Bruckner; Fuel, 12, 222 (1933)

115) R.S. Asbury; Ind. Eng. Chem. 28, 687 690 (1936)

116) I. G. C. Dryden and K. S. Pankhust; Fuel, 34, 363 366 (1955)

117) W. D. Hertog and N. Berkowitz; Fuel, 37, 358 361 (1958)

118) J. K. Brown and I. G. C. Drryden; J. $o^{f}$ Inst. of Fnel, 31, 259 (1958)

119) H. H. Lowry; 前出 1, 729 739 (1947)

120) G. R. Oxley; Fuel, 37, 19 (1958)

121) G. I. T. Mcconnel and F. J. Pinchin; Fuel, 38, 252 (1959)

122) A. Ladam und P. Payen; Brenn.-Chem, 41, 106 (1960)

123 ）武谷愿，久郷昌夫；燃協誌 $32,557 \sim 568$ 昭 28

124）吉田雄次；燃協誌 $37,617 \sim 620$ 昭 33

125）大内公耳；1959 年石炭利用技術会議会議録 5, 111 114 昭 35

126）前出 114）117）123）を参照

127) A. H. Clark and R. V. Wheeler; J. of Chem. Soci. 103, 1704 (1913)

128）伊木貞雄；石炭抒よびその試験法 164 167 昭 16

129) D. T. Jones and R. V. Wheeler; J. of Chem. Soci, 109, 707 714 (1916)

130) K. Bunte, et al; Fuel, 12, 222 (1933)

131) G. Agde und R. Hubertus; Brenn.-Chem. 15, 149 (1936)

132) J. M. Pertierra; J. of Inst. of Fuel, 9, 16 (1935)

133）黑川真武；応用燃料化学上巻 43 , 昭 24

134) R. E. Brewer and R. G. Atkinson; Ind. Eng. Chem. Anal., Ed. 8, 443 449 (1936)

135) R. E. Brewer and J. E. Triff; Ind. Eng. Chem., Anal. Ed. 11, 242 247 (1939)

136) H. H. Lowry; Chemistry of Coal Utilization, 1, 220 234 (1947)

137) P. J. Wilson; Coal, Coke and Coal Chemi- 
cals, $81 \sim 83(1949)$

138) 吉田雄次, 山口潔; コークスの研究(然協編) 4, $5 \sim 10$, 昭 28

139）武谷愿, 久鄉昌夫; 燃協誌, $32,557 \sim 568$, 昭 28

140) J. D. Davis; Ind. Eng. Chem., Anal. Ed. 3, 43〜 45 (1931)

141）久田清明, 城本義光; コークスの研究 (燃協編) 4, $14 \sim 26$, 昭 28

142) H. H. Lowry; 前出 $284 \sim 287$ (1947)
143) J. Naziakiewicz; Coke and Gas, 19, 193 194 (1957)

144）久郷昌夫, 工化雑； $54 ， 628 \sim 630$ (1951)

145）井田四郎，鎌田保；製鉄研究，207，532 543 昭 29

146) D. W. Van Krevelen, et al, Fuel, 33, 79 87, 338 347 (1954) 36, 313 320 (1957), Coal Science 151 164 (1957)

147) H. N. M. Dormans ; Fuel, 36, $321 \sim 339$ (1957)

\title{
Manufacture of Briquette Coke for Blast Furnace, Using the Poorly Caking Japanese Coal as Main Raw Materials (II)
}

\author{
by Shiro Ida
}

(Technical Research Institute, Yawata Works, Yawata Iron and Steel Co. Ltd.)

SYNOPSIS : - In the previous report, it was clarified that the qualities of coke improved, owing to elevation of coking properties of coal during carbonization from a view point of coke manufacture and physical changes in coking process by briquetting low-or non-caking coal, as compared with non-briquetting.

In this study, the author investigated the relation between briquetting pressure and the space of coal particles and moreover relative relations among briquetting conditions, the amount of $\alpha$-picoline extracts of coal and characteristics of $\alpha$-picoline extracts. From these results, coking mechanism of briquette coal has become clear. 